\title{
Pengembangan Model Pembelajaran PBL Berbasis Blended Learning pada Mahasiswa PGSD UNU Blitar
}

\author{
Cindya Alfi ${ }^{(1),}$ Kistin Restu Perdana ${ }^{(2)}$ \\ ${ }^{1}$ Universitas Nahdlatul Ulama Blitar, Indonesia \\ ${ }^{2}$ Universitas Negeri Malang, Indonesia \\ Email: ${ }^{1}$ Cindyalfi22@gmail.com, ${ }^{2}$ katakistin@gmail.com
}

\section{Tersedia Online di \\ http://www.jurnal.unublitar.ac.id/in dex.php/briliant}

\begin{tabular}{l}
\hline Sejarah Artikel \\
\hline Diterima pada 13 November 2019 \\
Disetujui pada 25 November 2019 \\
Dipublikasikan pada 30 November \\
2019 Hal. 539-547 \\
\hline
\end{tabular}

Kata Kunci:

PBL, Blended Learning

DOI:

http://dx.doi.org/10.28926/briliant. v3i4.412

\begin{abstract}
Abstrak: Penelitian ini memiliki tujuan untuk mengembangkan pembelajaran berbasis masalah (PBL) berbasis blended learning agar mahasiswa lebih menguasai pembelejaran dengan memanfaatkan teknologi dan pemecahan masalah. Model pengembangan Dick and Carey. Hasil penelitian menyatakan bahwa hasil validasi ahli pembelajaran diperoleh nilai $90 \%$, uji coba kelompok kecil yang dilakukan di offering B semester 1 PGSD UNU Blitar diperoleh presentase sebesar $85 \%$. Hasil uji coba lapangan dari angket subjek ujicoba diperoleh nilai $90 \%$. Artinya produk yang dikembangkan berupa model PBL berbasis Blended learning dalam kualifikasi sangat valid/layak sehingga secara umum tidak perlu revisi.
\end{abstract}

\section{PENDAHULUAN}

Saat ini pendidikan sudah dijadikan sebagai tolak ukur kemajuan negara. Hal tersebut berkaitan dengan penyiapan sumberdaya manusia yang berkualitas untuk pembangunan bangsa. Peran pendidikan memberikan bekal individu dalam mengembangkan diri dan memecahkan segala permasalahan sehari-hari. Perguruan tinggi merupakan salah satu lembaga pendidikan tingkat lanjut yang menyelenggarakan pendidikan. Menurut UU No. 12 Tahun 2012, Pendidikan Tinggi mencakup program diploma, sarjana, magister, doktor, dan profesi, serta program spesialis, yang diselenggarakan oleh perguruan tinggi berdasarkan kebudayaan bangsa Indonesia.

Pendidikan tinggi harus berupaya mendorong peserta didiknya agar mampu untuk beradaptasi terhadap perubahan masyarakat dan perkembangan Iptek yang sangat pesat (UU No. 12 Tahun 2012). Menurut World Economic Forum 2016, di tahun 2020 kemampuan yang diprediksi akan dibutuhkan yaitu pemecahan masalah, kreativitas, berpikir kritis, people management dan sebagainya. Oleh karena itu, muncul inovasi blended learning yang didesain berbasis masalah.

Upaya untuk mendorong mahasiwa agar menguasai teknologi yakni dengan menerapkan pembelajaran blended learning. Blended learning menggabungkan pembelajaran tatap muka dengan memanfaatkan internet sebagai sarana membantu proses pembelajaran dan pengajaran (Dikti; 2010). Metode ini tergolong baru penerapannya dalam dunia pendidikan. Menurut Sandi (2012) 
penerpaan blended learning dapat menambah alokasi waktu pembelajaran yang dilaksanakan mahasiswa. Penelitian yang dilaksanakan K. Gavin membuktikan bahwa PBL memiliki kesesuaian karakteristik ketika dipadukan dengan blended learning sehingga tercipta pembelajaran yang memuat pemecahan masalah, inovasi, berkelompok dan kemampuan presentasi.

Pada tingkat perguruan tinggi kemampuan memecahkan masalah sangat diperlukan. Berdasarkan studi pendahuluan melalui wawancara dengan dosen PGSD UNU Blitar bahwa kemampuan memecahkan masalah dan kemajuan teknologi saat ini belum diakomodasi kedalam proses pembelajaran dengan optimal, sehingga para mahasiswa kurang mampu dalam memecahkan masalah berdasarkan kehidupan nyata serta dalam proses pembelajaran peserta didik belum dapat memanfaatkan teknologi. Kegiatan pembelajaran dikelas hanya sebatas dosen menjelaskan materi kepada mahasiswa melalui PPT yang selanjutnya aktivitas dikelasa berupa tanya jawab.

Adanya permasalah tingkat penguasaaan teknologi dan rendahnya kemampuan memecahkan masalah, maka perlu adanya suatu terobosan dalam mendesain pembelajaran yang inovatif. Pembelajaran inovatif yang ditawarkan yakni pengembangan desain pembelajaran yang dikemas dalam pembelajaran berbasis masalah dan dipadukan dengan blended learning. Pembelajaran berbasis masalah merupakan model pembelajran yang memuat langkah pembelajaran investigasi, eksplanasi, dan pemecahan masalah yang diawali dari permasalahan nyata sehari-hari (Oguz-Unver dan Arabacioglu, 2011). Selain itu, pembelajaran berbasis masalah didesain untuk mendorong peserta didik dapat melakukan pemecahan masalah dan dapat dilaksanakan dalam kelas konvensional dan kelas virtual sehingga sesuai diterapkan pada era kekinian.

Upaya pemecahan masalah, dapat dipadukan dengan memanfaatkan teknologi pembelajran yang sedang berkembang pesat saat. Peneliti memilih PBL berbasis blended learnig model tersebut berakar dari permasalahan yang berasal dari lingkungan peserta didik sehingga peserta didik mampu memecahkan masalah melalui serangkain aktivitas PBL dengan efektif dan efisien. Menurut Darmawan (2014) blended learning ini berdasarkan perpaduan dan keterkaitan berbagai model pembelajaran yang dipilih dan disesuaikan guna mengoptimalkan proses dan layanan pembelajaran dengan memanfaatkan teknologi. Pembelajaran yang dimaksud yaitu menggabungkan pengajaran klasikal (tatap muka) dengan pengajaran online. Berkaitan dengan blended learning, pembelajaran tersebut syarat dengan penggunaan teknologi yang berkembang saat ini sehingga peserta didik lebih aktif, komunikasi lebih lebih baik dan meningkatkan kualitas pembelajaran memecahkan masalah.

Model pembelajaran yang didesain akan dikembangkan secara lebih operasional sehingga mudah dan menarik untuk diterapkan di perguruan tinggi. Pengembangan model pembelajaran berdasarkan berkontribusi hasil desain pembelajaran yang sesuai dengan kebutuhan di lapangan yang dapat mengembangkan kemampuan memecahkan masalah serta berbasis teknologi. Pengembangan pembelajaran ini didasarkan pada sintaks model pembelajaran PBL berbasis blended learning beserta perangkat pemebelajaran yang meliputi RPP, media, lembar Worksheet, dan penilaian. Harapannya dengan desain pembelajaran inovatif tersebut mampu meningkatkan penguasaaan teknologi mahasiswa dan kemmpuan memecahkan masalah.

540 BRILIANT: Jurnal Riset dan Konseptual Volume 4 Nomor 4, November 2019 


\section{METODE}

Penelitian dan pengembangan Dick, Carey \& Carey (2001) ada 9 langkah. Namun, model pengembangan ini dimodifikasi menjadi delapan langkah yang disesuaikan dengan kebutuhan peneliti. Berikut langkah model akan dilaksanakan sebagai berikut: (1) identifikasi kebutuhan, (2) analisis pembelajaran, (3) merumuskan tujuan pembelajaran, (4) mengembangkan instrumen penelitian, (5) mengembangkan strategi pembelajaran, (6) pengembangan dan pemilihan bahan ajar, (7) mendesain dan melaksanakan formatif, (8) merevisi produk.

Penelitian ini menggunakan 2 tahap uji coba yaitu, uji coba tahap awal dan uji coba utama. Uji coba dilakukan di pada peserta didik prodi PGSD UNU Blitar. UNU Blitar terletak di Jln Masjid No.22. Lokasi penelitian uji coba produk yakni Universitas Nahdlatul Ulama Blitar. Kedua tahap uji coba dilaksanakan guna mengetahui keefektifan, kelayakan dan kepraktisan model pembelajaran PBL berbasis blended learning. Subjek uji coba yaitu pengguna yang terdiri atas dosen prodi PGSD dan peserta didik PGSD UNU Blitar semester 1 angkatan 2017.

Instrumen dalam penelitian ini yaitu angket dan lembar observasi model pembelajaran PBL berbasis blended learnimg. Teknik analisis data yang digunakan yaitu analisis data kualitatif untuk menganalisis data yang diperoleh dari saran/masukan serta hasil observasi. Sedangkan skor angket respon pengajar dan peserta didik/ mahasiswa menggunakan analisis data kuantitatif.

\section{HASIL}

Berdasarkan hasil ujicoba validasi ahli terhadap produk model pembelajaran PBL berbasis Blended learning diperoleh hasil perhitungan persentase sebesar $90 \%$. Artinya produk yang dikembangkan berupa model PBL berbasis blended learning dalam kualifikasi kualifikasi sangat valid/layak sehingga secara umum tidak perlu revisi. Upaya penyempurnaan produk peneliti berdasarkan saran dan komentar dari ahli pembelajaran adalah alur model pembelajaran perlu disusun lebih sistematis dan perlu pemantapan materi yang terdapat dalam model supaya mahasiswa mampu menganalisa suatu permasalahan dan mencari pemecahan masalah tersebut sesuai dengan lingkungan masingmasing.

Model pembelajaran PBL berbasis blended learning selanjutnya diujicobakan pada mahasiswa OFF B PGSD angkatan 2017 UNU Blitar. Prosedur uji coba penelitian ini bekerja sama dengan dosen mata kuliah lainnya yang bertindak sebagai observer. Setelah pembelajaran berakhir, dosen dan mahasiswa mengisi angket kepraktisan dan ke efektifan dengan memberikan penilaian, kritik dan saran. Ujicoba I dalam kelompok kecil kelemahannya adalah belum siapnya akses internet yang dimilikioleh mahasiswa. Hal ini tentunya bisa menghambat proses pembelajaran yang mengakibatkan kurang tercapainya target pembelajaran yang direncanakan. Peran akses internet dalam blended learning adalah kunci utama. Pembelajaran yang efektif dapat dipandang sebagai pembelajaran yang memanfaatkan teknologi informasi dan komunikasi sebagai alat bantu pemebelajaran secara optimal.

Produk yang dikembangkan berupa model PBL berbasis blended learning selanjutnya diuji cobakan kepada mahasiswa prodi PGSD off B 2017 UNU Blitar. 
Prosedur pada ujicoba produk yaitu peneliti berperan sebagai pengajar, sedangkan observer dosen mata kuliah yang sama namun mengajar dikelas yang berbeda. Setelah pembelajaran selesai, mahasiswa mengisi angket efektifitas dan kepraktisan dengan cara memberi penilaian, komentar dan saran pada angket yang telah disediakan peneliti.

Berdasarkan pengolahan data uji coba kelompok kecil diperoleh hasil 85\%. Artinya model PBL berbasis blended learning termasuk pada kategori sangat efektif dan praktis sehingga dapat dikatakan layak digunakan dalam penerapan pembelajaran. Peneliti memerhatikan beberapa saran dan kometar yang telah diberikan oleh subjek uji berupa saran penyempurnaan produk yang dikembangakan agar mencapai target yang telah ditetapkan serta alokasi waktu bisa diperpanjang supaya pembelajaran berlangsung secara maksimal. Pembelajaran menggunakan blended lebih sebenanya bersifat fleksibel. Artinya pembeljaran dapat dilaksanakan secara tatap muka dan secara offline atau kelas virtual.

Uji coba II selanjutnya dilaksanakan di lapangan. Hasil pengolahan data yang diperoleh sebesar 93,3\%. Artinya model pembelajaran yang telah dikembangkan termasuk kategori sangat praktis dan sangat efektif sehingga dapat diterapkan dalam pembelajaran. Secara keseluruhan produk yang dikembangan termasuk pada kategori valid, praktis dan efektif serta layak digunakan. Namun ada beberapa saran dari ahli yang tetap perlu diperhatikan terkait dengan pembelajaran dan ujicoba dilapangan.

\section{PEMBAHASAN}

Produk yang telah dikembangkan berupa model Problem Based Learning berbasis Blended Learning untuk mahasiswa PGSD UNU Blitar Off B 2017. Produk yang dikembangkan sudah divalidasi oleh ahli pembelajaran dan telah diujicoba lapangan I dan ujicoba lapangan II. Produk yang dikembangan didesaing sesuai dengan kubutuhan lapangan yang empirik. Pengembangan produk ini memperhatikan aspek mahasiswa, isi pembelajaran, capaian dan model pembelajaran, sumber media serta penilaian.

Mahasiswa memiliki peran menjadi objek dalam pembelajaran. Penelitian pengembangan model PBL berbasis blended learning mengharuskan mahasiswa untuk aktif dalam menggali, mencari, dan mengolah data, berpikir, berkomunikasi, dan di akhir tahap dapat menyimpulkan guna mendapatkan solusi atau pemecahan maslah atas permasalahan yang terjadi di lingkungan sekitarnya dengan cara yg efektif dan efisien dimana mahasiswa tidak perlu bertatap muka dalam pembelajarannya. Menurut Siahaan (2003) pembelajaran online pada blended learning dimungkinkan dapat mengembangkan fleksibilitas belajar yang tinggi. Hal tersebut senada dengan pendapat dari Waryanto (2006) bahwa mahasiswa dapat mengakses materi-materi pembelajaran dan dapat berkomunikasi dengan teman ataupun dosen setiap waktu sehingga mahasiswa akan lebih memantapkan penguasaaan materi pembelajaran.

Materi dalam pembelajaran berisi informasi yang diberikan oleh pendidik kepada mahasiswa supaya mahasiswa mencapai kompetensi tertentu dalam pendidikan. Menurut Arsanti (2018) Materi pembelajaran tersebut memuat beberapa aspek kompetensi meliputi pengetahuan, sikap, dan keterampilan yang harus dikemas dalam sebuah pembelajaran oleh pendidik dan harus dipelajari oleh

542 BRILIANT: Jurnal Riset dan Konseptual Volume 4 Nomor 4, November 2019 
mahasiswa guna mencapai tujuan pembelajaran yang sudah dirumuskan sesuai SK dan KD. Secara spesifik, berbagai materi ajar yang meliputi aspek pengetahuan (fakta, konsep, prinsip, prosedur) sikap atau nilai, dan keterampilan. Oleh karena itu, materi pembelajaran disusun secara sistematis memuat pengetahuan, sikap, dan ketrampilan yang disajikan dalam pembelajaran kelas virtual dan kelas tatap muka.

Capaian pembelajaran merupakan aspek penting dalam penyususnan rencana pembelajaran. Menurut Kemenristekdikti (2016) kemampuan yang diperoleh melalui proses internalisasi pengetahuan, sikap, keterampilan, kompetensi, dan akumulasi pengalaman kerja itulah yang dikatakan capaian pembelajaran. Selain hal tersebut, capaian pembelajaran memuat kompentensi yang harus mahasiswa capai dalam setiap pembelajaran selama satu semester. Capaian pembelajaran (CP) terdiri dari capaian pembelajaran umum dan spesifik. Hal tersebut sesuai arahan dari Kemenristekdikti (2016) bahwa Capaian Pembelajaran Lulusan meliputi aspek-aspek yaitu Sikap, Pengetahuan, Keterampilan umum, dan keterampilan khusus yang telah dirumuskan serta disesuaikan dengan jenjangnya. Capaian pembelajarn lulusan ini bersifat umum terhadap mata kuliah, oleh karena itu capaian tersebut perlu diturunkan menjadi capaian pembelajaran mata kuliah (CPMK). Capaian mata kuliah akan dibagi lagi menjadi beberapa sub capaian pembelajaran mata kuliah (Sub-CPMK) atau sering disebut lesson learning outcomes (Bin, 2015; AUN-QA, 2015).

Aktivitas mahasiswa dalam upaya memperoleh informasi maupun kompetensi baru sesuai dengan capain pembelajaran disebut dengan pengalaman belajar. Menurut Sanjaya (2008) menyatakan bahwa ada beberapa pertimbangan dalam menentukan pengalaman belajar, antara lain: pengalaman belajar sesuai dengan capaian pembelajaran yang telah dirumuskan, sesuai dengan jenis bahan atau materi siswa, ketersediaan sumber belajar, dan pengalaman belajar harus sesuai dengan karakteristik siswa.

Model pembelajaran yang digunakan yakni pembelajaran berbasis masalah yang dipadukan dengan blended learning. Menurut Sumarmi (2012) $\mathrm{PBL} /$ pembelajaran berbasis masalah merupakan suatu model pembelajaran yang berfokus pada siswa serta memberikan arahan agar menjadi pembelajar mandiri dan terlibat langsung secara aktif dalam pembelajaran secara berkelompok. Sedangkan blended learning merupakan sebuah pembelajaran yang memuat kolaborasi tatap muka dan pembelajaran di kelas virual. Bliuc et al (2007) mengungkapkan 'Blended learning' describes learning activities that involve a systematic combination of co-present (face-to-face interactions and technologically-mediated interactions between students, teachers and learning resources. Jadi, blended learning dalah pembelajran yang mengintegrasikan pengalaman belajar secara tatap muka dan online dengan memanfaatkan sumber daya jaringan internet sebagai suplemen belajar.

Pembelajaran yang dikembangakan merupakan model PBL yang memanfaatkan kelas tatap muka dan kelas virtual dalam pelaksanaan pembelajarannya. Artinya mahasiswa melaksanakan serangkaian langkah pembelajaran memecahkan masalah melalui tatap muka dan virtual. Tahapan yang telah dilaksanakan mahasiswa di kelas nyata dan kelas virtual, meliputi: (1) mahasisawa melakukan orientasi masalah, (2) melakukan pengorganisasian mahasiswa dalam pembelajaran, (3) mendampingi dan melakukan pembimbingan 
proses penyelidikan secara individual maupun kelompok, (4) pengembangan dan penyajian hasil karya, (5) Aanalisis dan evaluasi proses pemerolehan solusi atas masalah dengan waktu yang sangat efektif dan efisien.

Tahap awal mahasiswa melakukan orientasi terhadap masalah. Pada tahap ini pengajar menyampaikan tujuan pembelajaran harus dicapai oleh mahasiswa. Selanjutnya mahasiswa harus sudah memiliki akun edmodo dan telah terdaftar di kelas online yang seduh dibuat. Selain hal tersebut, pengajar membantu mahasiswa yang mengalami kesulitan mendaftarkan diri pada kelas online. Selanjutnya pengajar melakukan pengorganisasian mahasiswa dengan cara membagi mahasiswa menjadi beberapa kelompok serta menugaskan mahasiswa menganalisis artikel tentang permasalahan atau isu-isu terkini terkait dengan HAM, Pancasila Globalisasi, Kesatuan dan persatuan yang berada disekitar mahasiswa. Penugasan dikerjakan sesuai dengan format Worksheet yang diberikan oleh pengajar.

Tugas selanjutnya, mahasiswa harus merancang aktivitas penyelesain masalah dari artikel yang ditemukan. Tujuan penugasan tersebut agar kemampuan bernalar mahasiswa berkembang dengan baik. Hal tersebut karena mahasiswa dipersiapkan untuk merancang langkah-langkah menemukan fenomena yang tepat termasuk dalam kategori permasalahan yang berkaitan dengan negara dan ketata negaraan. Dalam kelas online, pengajar memeberikan instruksi dan motivasi mahasiswa agar aktif bertukar pendapat atau diskusi tentang pemilihan permasalahan yang patut dicari solusinya disertai diskusi tentang permasalahan yang ditemukan oleh mahasiswa.

Tahap kedua adalah pengorganisasian mahasiswa dalam pembelajaran. Pengajar melakukan penyampaian dan penjelasan materi tentang masalah yang berkaitan dengan negara secara umum, selanjutnya mahasiswa aktif mencari dengan cara membaca artikel pendukung atau sumber pendukung lainnya yang terdapat pada kelas online sebagai pengetahuan tambahan dalam menemukan solusi permasalahan yang dipilih mahasiswa. Aktifitas tersebut mendorong mahasiswa secara aktif mampu mendefinisikan masalah dan mencari dasar teori sebagi acuan pemecahan masalah.

Tahap selanjutnya, pengajar mendampingi dan melakukan pembimbingan proses penyelidikan secara individual maupun kelompok. Tahap ini mahasiswa berperan aktif mengidentifikasi masalah yang mana selanjutnya dianalisis secara berkelompok. Dengan adanya proses indentifikasi masalah, komunikasi antar anggota kelompok harus lebih di intensifkan. Pengajar juga dapat membimbing dan mengarahkan mahasiswa guna menemukan pemecahan masalah atas permasalahan tersebut melalui kelas online. Mahasiswa dan Pengajar dapat memanfaatkan kelas online untuk berdiskusi kapanpun sehingga kegitaan pembelajarn akan lebih efektif dan efisien. Proses identifikasi dan analisis masalah memiliki tindak lanjut berupa tanggapan dan solusi yang berbeda dari masing-masing mahasiswa.

Dosen menstimulus mahasiswa agar mampu mengaitkan masalah satu dengan masalah lain dan mengevaluasi berdasarkan fakta di lapangan. Langkah selanjutnya mahasiswa menarik kesimpulan bagaimana pemecahan masalah yang tepat terhadap fenomena yang ditemukan. Mahasiswa dapat berkembang melaluii proses itu terjalin berupa kerjasama dan tuntutan agar dapat memecahkan masalah.

544 BRILIANT: Jurnal Riset dan Konseptual

Volume 4 Nomor 4, November 2019 
Tahap selanjutnya adalah pengembangan dan penyajian hasil karya. Mahasiswa berkesempatan menyajikan hasil kerja berupa presentasi virtual dengan worksheet yang di upload dikelas virtual. Selanjutnya mahasiswa lain diberi kesempatan memberikan tanggapan atau pertanyaan terkait materi kelompok yang diupload di kelas online. Presentasi bertujuan agar mahasiswa dapat mengemukakan pendapat maupun bertanya serta mengembangkan ketrampilan berpikir kritis atas setiap tanggapan, pertanyaan serta jawaban yang diberikan.

Tahap terakhir yaitu aanalisis dan evaluasi proses pemerolehan solusi atas masalah. Mahasiswa di dampingi pengajar melakukan penarikan kesimpulan hasil pembelajaran. Refleksi dapat juga dilakukan pada kelas tatap muka. Mahasiswa yang kurang memahami hasil pembelajaran dapat bertanya di kelas online. Melaui kegiatan presentasi tersebut ditentukan solusi yang paling tepat guna mengatasi permasalahan. Selanjutnya dilakukan perbaikan pada lembar aktivitas mahasiswa atau worksheet.

Pembelajaran dengan PBL berbasis blended learning mampu membelajarkan mahasiswa dengan efektif dan efisien. Senada dengan pendapat Sandi (2012) bahwa pembelajaran dengan menerpakan blended learning dapat berlangsung lebih bermakna dan meberikan pengalaman belajar bagi mahasiswa karena materi yang disediakan telah dirancang dan disesuaikan sehingga lebih mudah dipahami. Mahasiswa melakukan diskusi pada kelas nyata dan virtual dalam rangka memecahkan masalah dan mencari solusi. Mahasiswa dapat belajar sewaktu-waktu terkait materi yang dipelajarii. Dengan demikian, apa yang dipelajari mahasiswa menjadi lebih mudah dipahami mahasiswa.

Kegiatan pembelajaran berbasis masalah dengan blended learning melibatkan kreatifitas penuh. Kreatifitas tersebut berupa kegiatan mengamati lingkungan sekitar, menemukan konsep yang tepat guna proses pemecahan masalah serta melatih kemampuan bekerjasama dalam bekerja kelompok. Tahapan tersebut membentuk ketrampilan bernalar dengan baik karena secara mandiri siswa memutuskan penemuan masalah dan solusinya. Artinya, siswa mengetahui kebutuhan belajarnya sendiri.

Sumber dan media pembelajaran pada model yang dikembangan berasal dari lingkungan sekitar mahasiswa. Proses pembelajaran menggunakan model ini mahasiswa mengkonstruk pengetahuannya dari berbagai sumber yaitu masalah nyata disekitar mereka. Mahasiswa memilih alternatif pemecahan masalah dengan memaksimalkan seluruh pengetahuan dan keterampilan mereka, dengan demikian mahasiswa akan lebih aktif. Menurut Sumarmi (2012) siswa dapat menghadapi dan memecahkan permasalahan di lingkungan sekitarnya dengan cara berusaha mengerahkan segala kemampuan guna mendapatkan alternatif pemecahan masalah.

Penilaian merupakan komponen penting dalam pembelajaran yang berfungsi mengukur mahasiswa sudah mencapai capaian pembelajaran. Kemenristekdikti (2016) menyatakan penilaian merupakan proses pengidentifikasian, pengumpulan dan persiapam data beserta bukti pendukungnya guna langkah evaluasi proses dan hasil belajar mahasiswa. Proses penilaian berangkat dengan prinsip edukatif, otentik, objektif, akuntabel dan transparan. Aspek yang dinilai dari mahasiswa berupa sikap, ketrampilan umum dan khusus serta pengetahuan. 


\section{KESIMPULAN}

Hasil peneltian ini menyimpulkan bahwa produk yang dikembangan memiliki kualifikasi sangat valid/layak untuk digunakan; 2) hasil uji coba kelas kecil di off B semester pertama PGSD UNU Blitar menperoleh hasil bahwa model PBL berbasis blended learning termasuk pada kategori sangat efektif dan praktis sehingga dapat dikategorikan layak untuk digunakan dalam pembelajaran; 3) Hasil hasil uji coba lapangan yang diperoleh bahwa produk yang dikembangkan berupa model PBL berbasis Blended learning dalam kualifikasi sangat valid/layak sehingga secara umum tidak perlu revisidan dapat digunakan.

\section{SARAN}

Saran yang dapat disampaiakan adalah pemanfaatan, desiminasi, dan saran pengembangan produk lebih lanjut agar lebih sempurna dan terbaru. Saran pemanfaatan produk ini meliputi, 1) model yang dikembangkan hendaknya dapat diterapkan oleh dosen pada berbagai mata kuliah; 2) pemanfaatan blended learning hendaknya disesuaikan dengan kebutuhan mahasiswa, sehingga mahasiswa dapat memperoleh informasi yang dapat memperluas wawasanya; 3) agar pelaksanaan model berjalan dengan lancar hendaknya mahasiwa dikondisikan dengan baik; 4) pemanfaatan PBL berbasis blended learning hendaknya disesuikan dengan perkembangan masa kini.

Saran desiminasi yaitu model pembelajaran yang dikembangkan ini dibuat berdasarkan kebutuhan lapangan. Jika produk ini akan dipakai oleh pihak lain maka perlu diperhatikan kebutuhan lapangan, yang artinya model ini dapat direvisi sesuai dengan kebutuhan. Untuk pengembangan produk lebih lanjut, peneliti memberikan saran yaitu 1) mengembangkan CD interaktif implementasi model yang dikembangkan; 2) menyempurnakan lagi langkah-langkah pembeljaran di kelas tatap muka dan kelas virtual supaya alokasi waktu yang tersedia dapat dimanfaatkan dengan tepat.

\section{DAFTAR RUJUKAN}

Arsanti, Meilan. 2018. Pengembangan Bahan Ajar Mata Kuliah Penulisan Kreatif Bermuatan Nilai-Nilai Pendidikan Karakter Religius Bagi Mahasiswa Prodi PBSI, FKIP, Unissula. Jurnal Kredo Vol 1(2): 71-90. http://jurnal.umk.ac.id diakses 11 November 2019

AUN-QA. 2015. Guide to AUN-QA Assessment at Programme Level Version 3.0. Bangkok: ASEAN University Network.

Bin, J. O. 2015. Living Better. (AUN-QA Network) Retrieved Maret 2016, from http://livingbetterforhappiness.blogspot.co.id/2015/12/the tenprinciplesbehind-aun-qa-model.html

Darmawan, Deni. 2014. Pengembangan E-Learning teori dan Desain. Remaja Rosdakarya: Bandung

Direktorat Ketenagaan: Direktorat Jenderal Pendidikan Tinggi. 2010. Modul Pendamping Pengembangan BERMUTU. Jakarta: Kementrian Pendidikan Nasional

Kemenristekdikti. 2016. Panduan Penyusunan Kurikulum Pendidikan Tinggi. https://belmawa.ristekdikti.go.id (online) diakses 11 November 2019 
Oguz-Unver, Ayse dan Arabacioglu, Sertac. 2011. Overviews on Inquiry Based and Problem Based Learning Methods. Western Anatolia Journal of Education Science 303-310

Sandi, Gede. 2012. Pengaruh Blended Learning Terhadap Hasil Belajar Kimia Ditinjau Darri Kemandirian Siswa. Jurnal Pendidikan dan Pengajaran, Jilid 45(3):241-251

Siahaan, Sudirman. 2003. E-Learning (Pembelajaran Elektroni) sebagai salah satu Alternatif Kegiatan Pembelajaran. Jurnal Pendidikan dan Kebudayaan No.042 Mei 2003. Jakarta: Depdiknas.

Sumarmi. 2012. Model-Model Pembelajaran Geografi. Aditya Media Publishing: Malang

Undang-Undang Republik Indonesia No.12 Tahun 2012. http://sumberdaya.ristekdikti.go.id/ (online) diakses 11 November 2019

Waryanto, Nur Hadi. 2006. Online Learning sebagai salah satu Inovasi Pembelajaran. Jurnal Phitagoras Vol (2) 1: 10-23. http://staff.uny.ac.id/sites/default/files/132304807/Online\%20Learning\%2 0sebagai\%20Salah\%20Satu\%20Inovasi\%20Pembelajaran.pdf. Diakses 11 November 2019 